\title{
Opportunities and Challenges of Islamic Education in the Pandemic Era (Case Study in Rawa Mekar Jaya, Tanggerang)
}

\author{
$1^{\text {st }}$ Siti Masyitoh ${ }^{1}, 2^{\text {nd }}$ Dini Permana Sari ${ }^{2}, 3^{\text {rd }}$ Kartika Sari $^{3}, 4^{\text {th }}$ Arif Zamhari ${ }^{4}$, \\ $5^{\text {th }}$ Nur Sodik $^{5}, 6^{\text {th }}$ Mukhson Nawawi ${ }^{6}$ \\ \{siti_masyitoh19@mhs.uinjkt.ac.id ${ }^{1}$, dini_permana18@mhs.uinjkt.ac.id ${ }^{2}$, \\ kartika_sari19@mhs.uinjkt.ac.id ${ }^{3}$, arif.zamhari@uinjkt.ac.id ${ }^{4}$, nur.sodik@unindra.ac.id, ${ }^{5}$ \\ mukhson@uinjkt.ac.id $\left.{ }^{6}\right\}$
}

Postgraduate School Syarif Hiday atullah State Islamic University of Jakarta, Indonesia ${ }^{1,2,3,4,6}$ Universitas Indraprasta PGRI ${ }^{5}$

\begin{abstract}
This research tries to analyze the opportunities and challenges of Islamic education in the pandemic era. The results showed that the opportunities for Islamic education were very high in the Pandemic era because the media used were based on technology to explore the sciences of digital Islamic education. The challenges of Islamic education in the pandemic era are very complex because Islamic education technology has not evenly distributed to all domains. The existence of economic, social and group disparities affects the use of uneven media, so innovation is needed to answer these challenges. This study uses a field research method that tries to analyze the research findings, data management techniques that are data reduction and data display. In contrast, data collection methods are interviews and observation. This research was conducted in Mekar Jaya area, South Tangerang by interviewing parents of students, directly and indirectly, to obtain: responsiveness, responses, perceptions and input.
\end{abstract}

Keywords: Challenges, Opportunities, Islamic Education, and Pandemics

\section{Introduction}

Today the presence of the coronavirus or better known as Covid -19 has become a pandemic for the world community, including Indonesia. The number of Covid 19 cases in Indonesia has even increased from July 2020 to October 2020, increas ing to more than two times. It can see from the data on July 10 showing 1,611 cases, and on October 10 there were 4,204 cases. ${ }^{1}$ This figure shows the case in Indonesia has not decreased even experienced a significant increase. Meanwhile, in a relatively long time, from March until July 2020, the Government has implemented various policy right to break the chain of transmission covid. The Government's efforts seek and implement solutions handling covid with trying to apply lockdown, social distancing, hand washing until the Large-scale Social Restrictions (PSBB).

The impact of Covid 19 feels in various aspects where crowded places are limited and even closed, such as tourist attractions or shopping centres and even places of worship. [1]

${ }^{1}$ Infografis COVID-19 dari Satuan Tugas Penanganan Covid 19, https://covid19.go.id/p/berita/infografiscovid-19-12-oktober-2020 
People directed to work from home (Work From Home), including in the field of education. Activities in schools have to stop (non-active), so that learning activities carried out at home, without meeting face to face in class (School From Home).

The most felt impact is the online learning system, where students learn from home using long-distance telecommunications devices. Until now (October 2020), there is still no certainty for school learning to reopen, so parents have to rack their brains to educate their children. It is where the problems of education and childcare arise. Parents feel tired, boredom, and stress, which results in mistakes in the treatment of children at home. [2] However, the concept of education with an online system must continue to implemented during pandemic conditions according to the direction of the Minister of Education and Culture, Nadiem Makarim in a coordination meeting with all regional heads in Indonesia. ${ }^{2}$

Parents and the community have also experienced positive and negative reactions regarding the online learning system. New problems that have arisen among parents and the community regarding this online learning system are starting to feel. Parents are required to have the ability to use technology and have technological devices such as gadgets or laptops as support and support for the implementation of learning from home. Another reality shows the inability of parents and students to use technology. Unequal social and economic disparities will have an impact on the ownership of educational technology facilities among certain groups.

This situation also occurs in Islamic education, where the learning process carries out online. Several studies have shown that students in undergoing learning with an online system for a long time experience boredom, boredom, resistance, and other destructive traits. [3]Therefore, parents have to spend extra energy to play themselves at home as teachers, mentors, facilitators, motivators and uswatun hasanah (role models) as well as entertainers. The multi-role of parents, especially mothers, aims to ensure that children continue to learn and educated following the Qur'an and hadith, without experiencing boredom and frustration, so the goals of education are well achieving.

According to Rachmadonna (2020), writing the Benefits of Smartphone Technology Among Students as Access to Learning During the Corona-19 Pandemic concludes that: gadgets are like friends. Because gadgets are always updated from day to day and are liked by the general public, including students, whose presence helps and useful in the learning process. According to him, online learning has the opportunity to break the chain of spreading covid 19. [4]

Islamic education is education based on the Koran and hadith as a source of learning to make students believe and fear Allah SWT, have noble morals, be intelligent, independent, wise and wise. It is in line with the goals of National education in Law No. 20 of 2003:

Education is carried out in a democratic and just manner and is not discriminatory by upholding human rights, religious values, cultural values, and national diversity with one systemic unity with an open and multi-meaning system. Besides, the implementation must also be in a lifelong process of cultivating and empowering students by modelling, the building will, and developing the creativity of students in the learning process through developing a culture of reading, writing, and arithmetic for all members of society empowering all components of society through participation in the implementation and quality control of educational services."

${ }^{2}$ Devira Prastiwi, "8 Arahan Mendikbud Nadiem Terkait Pembelajaran Siswa Terkini, dalam Liputan6, 3 September 2020, https://www.liputan6.com/news/read/4346613/8-arahan-mendikbud-nadiem-terkaitpembelajaran-siswa-terkini. 
The interest in achieving educational goals is currently homework for all Indonesians, including the people of South Tangerang in Mekar Jaya. Even though in South Tangerang Covid 19 has entered the yellow zone, it means that Covid cases have decreased. However, Islamic education institutions, including Islamic Boarding Schools, Madrasahs, Diniahs, RAs, and non-formal Islamic institutions such as TPQ, TPA, have not been allowed face-to-face learning. It has an impact on the psychological impact of parents and students who tend to experience boredom, as the authors mentioned above. Based on the above background, the authors are interested in conducting further research related to the opportunities and challenges of Islamic education in the pandemic era, with the research subject carrying out in the Mekar Jaya area of South Tangerang.

\section{The Covid 19 Pandemic}

The Covid 19 is a disease caused by the Novel Corona Virus (nCoV) while the number 19 shows 2019 as the beginning of its spread. Covid-19 (coronavirus disease 2019) is a new type of disease caused by a virus from the coronavirus class, namely severe acute respiratory syndrome coronavirus 2 (SARS-CoV-2), which is also often called the coronavirus. A new type of coronavirus that in humans causes common cold to serious illnesses such as Middle East Respiratory Syndrome (MERS) and Severe Acute Respiratory Syndrome (SARS). People with Covid 19 will show several symptoms such as flu or fever, runny nose, dry cough, sore throat, and headaches. Patients with severe symptoms may experience high fever, cough with phlegm or bleeding, shortness of breath, and chest pain. In general, three common symptoms can indicate a person is infected with COVID-19, namely: Fever (body temperature above $38^{\circ}$ C), dry cough, and shortness of breath.In addition to the above symptoms, some other symptoms rarely occur, namely: fatigue, muscle pain, chest pain, sore throat, headache, nausea or vomiting, diarrhoea, runny nose or stuffy nose, chills, sneezing and loss of taste. or smell. All of these symptoms can appear within two days to two weeks after a person is infect with the virus that causes it. In some sufferers, COVID-19 has no symptoms at all. However, these sufferers (people without symptoms / OTG) can still transmit COVID-19 to other people. .[5]

WHO (World Health Organization) announced the name of the disease caused by 2019 nCov, namely the coronavirus disease (Covid19). The first case of this disease occurred in the city of Wuhan, China, at the end of December 2019. WHO states that COVID-19 is transmitting through aerosols (particles of substances in the air) which only occur in certain medical procedures, such as bronchoscopy, endotracheal intubation, mucus suction, and drug administration. inhale through the nebulizer. [6]

Covid 19 is a serious concern in Indonesia because many sufferers from Indonesian society have died. According to data from the Accelerated Handling of COVID-19 of the Republic of Indonesia, the number of confirmed positive cases as of July 18, 2020, is 81,668 people with 3,873 deaths. Thus, the case fatality rate or death rate caused by COVID-19 in Indonesia is around $4.7 \%$. The case fatality rate is the percentage of the number of deaths from the total number of confirmed and reported positive cases of COVID-19. The case fatality rate data based on age groups are as follows: 0-5 years: 2.06\%, 6-17 years: $0.57 \%, 18-30$ years: $0.67 \%$, 31-45 years : $2.02 \%, 46-59$ years: $7.46 \%$ and $>60$ years: $16.1 \%$. Of all COVID-19 sufferers who died, $1 \%$ were age $0-5$ years, $0.7 \%$ were aged $6-17$ years, $3.3 \%$ were aged 18 30 years, $13.3 \%$ were aged $31-45$ years, 39, $8 \%$ were age $46-59$ years, and $42 \%$ were 60 
years and over. Meanwhile, based on gender, $60 \%$ of sufferers who died from COVID-19 were men, and the remaining $40 \%$ were women. ${ }^{3}$

Covid-19 is considering more dangerous or even fatal if it attacks older people, pregnant women, smokers, people with certain diseases, and people whose immune systems are weak, such as cancer sufferers,[7]Therefore, the Government implemented a policy to impose largescale lockdown and social restrictions (PSBB) to suppress the spread of this virus.

\section{Islamic Education in the Modern Era}

Education, in general, is a learning process for students (humans) to educate and mature students. Thus education does not only foster but also develops competencies, skills and attitudes of students in achieving happiness. [8] Islamic education is the science of education based on Islam, sourced from the al-Qur'an and hadith. The orientation of Islamic education towards the implementation of the sacred duties of a believer, namely as caliph and servant. In education, a teacher or education manager can carry out the syiar of Islam or $d a^{\prime} w a h$ in order to participate in enforcing the sentence of tauhid. Islamic education is a means to prepare a Muslim community who truly understands Islam. Therefore, Muslim educators have an obligation and responsibility to convey the knowledge they have to their students, both through formal and non-formal education by paying attention to what their students need. Islamic education prioritizes Islamic values and is focusing on the formation of humans who have good morals and are obedient and submit to Allah alone. [9]

In today's modern education, there has been a separation between worldly affairs and ukhrowi affairs. However, during the Covid 19 pandemic, Is lamic education should prioritize applied science which is applicable, not only in the religious sciences but also in the field of technology. That is so that mistakes do not occur so that it comes out of the essence of Islamic Education, which must maintain the relationship between humans and God.[8]Aruny Hayya Al Fadli in his journal entitled, The pandemic's relation to the earth's climate and the view of the holy text, concludes that the principles contained in the verses of the Koran have a significant role in educating society where humans are taught to become wise and aware caliphs and have a responsibility in maintaining, care for, manage and preserve all the potential that has been provided by Allah SWT on earth. Maintaining harmony between the world and the hereafter which includes the relationship between humans and God, in Islamic teachings, it includes four sides, namely (a) harmony with God, (b) harmony with society, (c) harmony with the natural environment, and (d) harmony with self. This suitability and harmony are closely related to the ethics of ecological utilization which by itself will be maximized and run according to the principles of divine provisions. So that between duties as caliph on earth and as a servant who must be obedient can run properly.[10]

During the current pandemic, Islamic education is facing the necessity to adapt to the demand to include science and technology in its educational curriculum. It is intended that students can use and master science and technology as support in learning success. The importance of integrating religious science with modern science so that there is no dichotomy between the two even synergizes between the two so that it becomes a provision for students to be ready to navigate the future of their lives. [9]

\begin{tabular}{|c|c|}
\hline & Covid \\
\hline
\end{tabular}

https://kemkes.go.id/resources/download/infoterkini 
Currently, the Islamic education model has undergone many changes as a result of the COVID-19 pandemic. The development and existence of the internet and social media, as well as restrictions on various religious activities, are challenges and opportunities for Is lamic education activities, including informal and non-formal institutions (such as mosques and prayer rooms). So the use of information technology in da'wah activities raises the concept of e-da'wah .[11]The application of e-da'wah in religious activities is an adaptation of new habits that must be started immediately by mosques and other Islamic education al institutions. The eda'wah application development model needs to develop to provide solutions for mosques so that they can continue to carry out their activities online. According to Syahrizal Dwi Putra in the journal of e-da'wah mobile application development model during the Covid-19 pandemic with the prototyping method, it is concluded the method of implementing Is lamic education in mosques can do by developing a prototyping method application and can be implemented through the e-da'wah mobile application so that it is for da'wah activities. very effectively done with features such as study schedules and materials, activity info, prayers, hadiths, videos, prophetic stories, inspirational stories and quotes that can be accessed anywhere with the help of the internet and Android mobile devices. [12]

\section{SWOT: Islamic Education in The Pandemic Era}

Analyzing current opportunities and challenges is very important for the achievement of the implementation of strategies, goals and targets for Is lamic education. The aim is to identify internal factors and external factors.It supports or hinders the activities of da'wah[13] [13]through Islamic education, especially in the application of online learning systems during the pandemic era.

The authors use a SWOT analysis (Strength, Weakness, Opportunity and Threat), as has been done by previous researchers to conduct educational analysis. [14] Providing a scientific recommendation for service efforts to achieve the goals of Islamic preaching or education, to give birth to changes in the social life of the public that is better, correct, advanced, and lively. On the other hand, without being based on this analysis, likely, planning of Islamic preaching and education activities cannot be born carefully, precisely, and strategically. SWOT analysis can be the basis for producing healthy and appropriate recommendations for strate gic planning and development of objectives for Islamic da'wah and education activities individually, communally, and socially. [15]With these recommendations, hoping that there will be the right policies for the implementation of Islamic da'wah and education with an online system in the pandemic era. However, in this analysis, the authors only limit and focus on opportunity and threat analysis.

The Covid-19 pandemic has had a massive impact on education. The implementation of the physical distancing policy becomes the basis for the implementation of online learning by utilizing information technology. Media is often using in online learning include Whatshap groups and Google Classroom, zoom and Google meet. The use of online learning with various media contains opportunities to improve the ability to use digital in education. However,some obstacles are experienced, such as inadequate facilities. According to $\mathrm{Ni}$ Komang Suni Astini, in her journal Challenges and Opportunities for Using Information Technology in Online Learning for the Covid-19 period, concluded that the results of the survey had opportunities and obstacles in implementing lectures on campus with an online system. $50 \%$ of students did not have laptops, and $80 \%$ of students said it was difficult to get a 
signal and wasteful use of this data packet. Learning becomes less effective because as many as $61.5 \%$ of students stated that they had never used online lecture media before the Covid-19 pandemic. However, online learning has also triggered the acceleration of the digital transformation of education. [16]Thus Covid-19 provides extraordinary opportunities for digital transformation towards the era of education 4.0. In contrast to the research conducted by Muhdi and Nurkolis in their journal The Effectiveness of Social Media-based E-Learning Policies in Early Childhood Education during the Covid-19 Pandemic, concluded the formulation of e-learning policies in early childhood education was beneficial. However, in implementation, it was less effective, due to obstacles, namely pedagogical constraints, technology, and economics.[17]

Research related to online learning using the WA group according to Nurul Astuty Yensy in the Whatsapp Group journal in terms of Student Learning Outcomes (Covid 19 Pandemic Period).Concludes lectures in mathematics statistics courses using WhatsApp Group media are quite useful where learning outcomes are higher than before lectures by using the WA Group. However, there are still weaknesses, including the signal is less supportive for students domiciled in the area, the memory of the cellphone becomes full of chats causing the internet connection to be slow and quite tiring because they have to go back and forth to see the chat. [18]

\section{Research Methodology}

\subsection{Types of Research}

This type of research is qualitative research, which is a research procedure that produces descriptive data in the form of written or spoken words from people and observed behavior. [19] This study aims to obtain a more transparent, more complete picture and information, and to make it easier for researchers to conduct observational research and interviews.In this field research, [20] the authors chose subjects as informants based on the incidental sampling technique, a total of 10 respondents, to parents in the Rawa Mekar Jaya village, South Tangerang.

\subsection{Data Retrieval Technique}

In terms of collecting this data, the writer goes directly to the object of research to get valid data, so the researcher uses the following methods:

a. Observation method or observation defining as systematic observation and recording of the symptoms that appear on the research object. This observation uses participatory observation, where the researcher is directly involved with the person's daily activities or who using as a source of research data[19] In this case, the researcher observed parents who were gathered and talked about the online learning system's problems. Observations are also carrying out to find out how parents treat their children.

b. Interview method (Interview). A face to face conversation with a specific purpose carried out by two parties, namely the interviewer (interviewer) who asks questions and the interviewee (interviewee) who provides answers to questions [19] Open-ended questions with an in-depth exploratory interview model, [19] to get more in-depth information. In this case, the researcher conducted two interviews with respondents at different times. In 
the second interview, the objective is to verify and, at the same time, test the validity of the data through triangulation. [19]

\subsection{Data Analysis Technique}

According to Miles and Huberman, three paths must be passed in analyzing data, namely data reduction, data dis play/presentation, and drawing conclusions or verification. [21]

Data reduction is defining as the process of selecting, focusing attention on simplifying, abstracting, and transforming "rough" data that emerge from field notes. The reduction is carried out since data collection, starting with summarizing, coding, exploring themes, and writing memos; to set aside irrelevant data or information, then the data is verified.

a. The display/presentation of data is the description of a group of structured information that provides the possibility of drawing conclusions and taking action. The presentation of qualitative data is presenting in the form of narrative text, is design to combine information arranged in a coherent and easily understood form.

b. Drawing conclusions or verification is the last activity of qualitative research.

\section{Finding}

Rawa Mekar Jaya is a sub-district located in Serpong sub-district, South Tangerang City, Banten province, Indonesia. Data on Covid 19 cases in July 2020, the Rawa Mekar Jaya area is in a yellow zone, meaning that there have been several cases of Covid-19 with some local transmission. In this zone, PSBB can carry out partially and apply health protocols .Namely by identifying contacts of confirmed cases (contact tracing) and conducting independent testing, monitoring and isolation. Currently, public adherence to health protocols has only reached $82 \%$ of the ideal target, namely $90 \%$. As of July 15, 2020, there are still $8 \%$ of South Tangerang city people who have not complied with health protocols. ${ }^{4}$ The school licensing policy in Tangsel has not even started with a face-to-face learning system because the number of positive cases of Covid-19 in Tangsel City as of July 15, 2020, reached 447 people. Of these, 331 patients are declaring cured. This figure increases by six patients from the latest data, namely 325 people. Currently, 34 people have died due to Covid, and 82 patients have tested positive for Covid. The latter is still undergoing treatment in hospitals and undergoing independent isolation. Specific data in the Rawa Mekar Jaya sub-district obtained data on July 17, 2020, with the following conditions: ODP $=20$ people, $\mathrm{PDP}=6$ people, confirmed positive $=$ seven people, one person died and recovered $=$ six people. $^{5}$

The authors conducted in-depth interviews related to Is lamic education's opportunities and challenges in the COVID-19 pandemic era. The author conducted interviews with the community, especially parents who have school-age children, Islamic education institutions and general education, both formal and non-formal.

According to M and SZ, they said: "Since studying at home using an electronic device in the form of a cellphone, I felt bothered, some work was neglected because I had to supervise and guide her learning by staying beside my child if my child is careless just a little playing

${ }^{4}$ Tria Sutrisna | Editor Irfan Maullana Tangerang selatan, kompas.com - Satuan Gugus Tugas Covid-19 kota Tangerang Selatan, 14/7/2020)

${ }^{5}$ Data Pantauan COVID-19 Kota Tangerang Selatan. Note : Last Update 17 Juli 2020 (Sumber data Gugus tugas COVID-19 Kota Tangerang Selatan) 
games." The same thing was conveyed by Z, "Since children study at home using cell phones, daily spending is limited because they have to provide credit or quota to be able to participate in learning, once they are not providing, my child gets angry and shows opposing behaviour. Meanwhile, suppose it is diverting to other activities. In that case, it tends to be difficult to direct and prefers to enter the room and sleep. " J and S said, "During the corona season, I invite my child to accompany me selling vegetables because I do not have an existing cellphone that can use as a learning tool." The five respondents indicated similarities regarding the difficulties in coping with children's learning behaviour, the problem of the cost burden that disturbs the economy (calculation of spending money) and learning facilities are not yet own.

In contrast to Pak JF, A, and K, who said, "Since I have to study at home using the internet, I feel light in teaching children because the children are clever in accessing the subject matter discussed by the teacher, and my child seems adept at using electronics. He can download, upload assignments and use learning media such as google classroom, zoom and Whatsapp. "L and B conveyed the same thing, "I feel that I have benefited from having an online learning method because I can supervise children, so I can better understand their character and habits." The results of the exposure of the two respondents showed that learning during the pandemic using technology made it easier for parents to teach and supervise children's learning. Studying at home can improve parents' understanding of their children's learning habits and habits.

The results of the observations on the respondents mentioned above reinforce the results of the interview, where a mother has difficulty controlling the child's behaviour so that the mother looks emotional (bursts out angry with loud words). Other respondents seemed to be directly involved in the learning process, helping their children learn. Meanwhile, other respondents continue to work with their children's help because they do not have a cellphone or laptop facilities.On the other hand, the respondent seems to be watching his child without being involved in learning.

Based on the results of observations and interviews with some of these parents, several points can conclude: first, Islamic education during the pandemic period presented obstacles for parents because daily activities were increasing, where parents had to ensure their children continued to learn, control and control children's behaviour in learn and have to master technology. It means that parents are involved in children's learning activities. Another obstacle is the inability to complete learning facilities due to economic factors so that children cannot follow the learning process with an online system.

Second, the opportunity for Islamic education in the pandemic era using internet or online network media has led students to be more creative in using technology. Also, technology makes it easier for children to absorb knowledge, including Islamic lessons using the audiovisual method. The existence of children and parents for a long time at home, almost 24 hours of interaction together, increases understanding of children's behaviour, character and habits in their daily lives. It will make it easier for parents to get to know their children better and improve the quality of the relationship between children and parents. 


\section{Conclusion}

The opportunity for Islamic education in the pandemic era is to facilitate the distance learning process. Learning materials that are easily accessible through technology become learning media that further enrich students' knowledge and increase student learning creativity. It is in line with the mission of the ministry of education and culture regarding Freedom of Learning, which means students are free to access learning content, including digital Islamic education materials. It means, students, learn to balance the balance between science and faith (religion), which is the goal of Islamic education.

The challenges of Islamic education in the Pandemic era are also evident in this study. Including economic and social disparities, where government policies have not provided educational technology facilities for free to all students. Second, it is necessary to have parents' readiness to treat children appropriately on the online learning system,so that children's learning tasks do not become a burden (additional work) for parents. Third, knowledge about the use of technology, not evenly distributed, so there is a need for digital literacy in parents and students to facilitate the learning process during a pandemic. 


\section{References}

[1] F. Irwan Widjaja, C. Gunawan Marisi, T. M. Tua Togatorop, and H. Hartono, "Menstimulasi Praktik Gereja Rumah di tengah Pandemi Covid-19," Kur. (Jurnal Teol. dan Pendidik. Agama Kristen), vol. 6, no. 1, pp. 127-139, 2020.

[2] A. K. Griffith, "Parental burnout and child maltreatment during the COVID-19 pandemic," $J$. Fam. Violence, pp. 1-7, 2020.

[3] W. Cao et al., "The psychological impact of the COVID-19 epidemic on college students in China," Psychiatry Res., p. 112934, 2020.

[4] Rachmadonn and A, "Manfaat Teknologi Smartphone Di Kalangan Pelajar Sebagai Akses Pembelajaran Di Masa Pandemi Corona-19," J. Pendidik. Islam, vol. I, no. 1, p. 22, 2012.

[5] H. Ahmed, M. Allaf, and H. Elghazaly, "COVID-19 and medical education," Lancet Infect. Dis., 2020.

[6] D. Cucinotta and M. Vanelli, "WHO declares COVID-19 a pandemic.," Acta bio-medica Atenei Parm., vol. 91, no. 1, pp. 157-160, 2020.

[7] H. Wang and L. Zhang, "Risk of COVID-19 for patients with cancer," Lancet Oncol., vol. 21, no. 4, p. e181, 2020.

[8] D. Sobel, "School Outdoors: The Pursuit of Happiness as an Educational Goal," J. Philos. Educ., 2020.

[9] M. Khoiruddin, "Pendidikan Islam Tradisional dan Modern," TASYRI' J. TARBIYAHSYARI'AH Islam., vol. 25, no. 2, pp. 92-105, 2018.

[10] A. H. Al Fadli, "RELASI PANDEMI TERHADAP IKLIM BUMI DAN PANDANGAN TEKS SUCI," J. Ilmu Agama Mengkaji Doktrin, Pemikiran, dan Fenom. Agama, vol. 21, no. 1, pp. $142-165,2020$

[11] M. A. Hureri, M. Roslan, and M. Tahir, "The Role of Media in Islamic Da'wah in a Plural Society," Muhammad, Role Media Islam. Da'wah a Plur. Soc. (November 28, 2019), 2019.

[12] S. D. Putra, T. F. Eldiana, and D. Aryani, "MODEL PENGEMBANGAN APLIKASI MOBILEE-DAKWAH DI MASA PANDEMI COVID-19 DENGAN METODE PROTOTYPING," J. Inf. Syst. Informatics Comput., vol. 4, no. 1, pp. 116-121, 2020.

[13] I. Tampubolon, "Analisis SWOT dalam Penelitian Manajemen Dakwah," Tadbir J. Manaj. Dakwah FDIK IAIN Padangsidimpuan, vol. 2, no. 1, pp. 93-108, 2020.

[14] A. C. Hadjichambis, P. Reis, and D. Paraskeva-Hadjichambi, "European SWOT analy sis on education for environmental citizenship," European SWOT analysis on education for environmental citizenship. Instituto de Educação, Universidade de Lisboa, 2019.

[15] A. S. Fahriana and M. Huda, "Application of Analysis of Strengths, Weaknesses, Opportunities, and Threats in Islamic Education Institutions," Istawa J. Pendidik. Islam, vol. 4, no. 1, pp. 50-64, 2019.

[16] N. K. Suni Astini, "Tantangan Dan Peluang Pemanfaatan Teknologi Informasi Dalam Pembelajaran Online Masa Covid-19," Cetta J. Ilmu Pendidik., vol. 3, no. 2, pp. 241-255, 2020.

[17] N. Nurkolis and M. Muhdi, "Keefektivan Kebijakan E-Learning berbasis Sosial Media pada PAUD di Masa Pandemi Covid-19," J. Obs. J. Pendidik. Anak Usia Dini, vol. 5, no. 1, p. 212, 2020.

[18] N. A. Yensy, "Efektifitas Pembelajaran Statistika Matematika melalui Media Whatsapp Group Ditinjau dari Hasil Belajar Mahasiswa (Masa Pandemik Covid 19)," J. Pendidik. Mat. Raflesia, vol. 05, no. 02, pp. 65-74, 2020.

[19] J. W. Creswell, "Research design: Qualitative and mixed methods approaches," London Thousand Oaks Sage Publ., 2009.

[20] U. Sekaran and R. Bougie, Research methods for business: A skill building approach. John Wiley \& Sons, 2016.

[21] H. Usman and P. S. Akbar, "Metode penelitian sosial," Jakarta Bumi Aksara, 2009. 